\title{
Multilingualism in Azerbaijan: The most Preferred Foreign Languages in Private Universities of the Country and Its Socioeconomic Aspects
}

\author{
Valida Karimova \\ Division of Graduate Studies and Research, Khazar University, Baku, Azerbaijan
}

Email address:

kerimovavalide@yahoo.com

\section{To cite this article:}

Valida Karimova. Multilingualism in Azerbaijan: The most Preferred Foreign Languages in Private Universities of the Country and Its Socioeconomic Aspects. International Journal of Education, Culture and Society. Vol. 2, No. 4, 2017, pp. 120-125. doi: $10.11648 /$ j.ijecs.20170204.13

Received: March 5, 2017; Accepted: May 31, 2017; Published: September 30, 2017

\begin{abstract}
The target reason for the present article analyzes the likelihood of foreign language in the education system of Azerbaijan: which examinations and deciding the most favored foreign language for this matter. Azerbaijan is a nation with customs of multilingualism. This examination was directed utilizing the graphic quantitative strategy including 301 understudies from two private Universities as a member. The instruments utilized for this examination study are the survey to distinguish whether the foreign language is bolstered among understudies in Azerbaijan, and which foreign language is favored most. Also, it was looked to inspect the relationship among factors of sex, social class, existing language abilities, and states of mind to the objective language inclination. It was found that language learning is bolstered by members, and English is the most favored foreign language. It demonstrates that multilingual societies like Azerbaijan are strong of language securing decisions that help protect and create multilingualism. In addition, it was found that mentality to foreign language learning itself vary because of salary level and existing language aptitudes.
\end{abstract}

Keywords: The English Language, Examine, Azerbaijan, Attitude, The Best Foreign Language Learning, Multilingualism

\section{Introduction}

The article exhibits and assesses the idea and significance of the relationship or even the contrast between the foreign languages, particularly English and Russian at our nation (Baku, Azerbaijan). Look at the best foreign language in the training arrangement of Azerbaijan, and deciding the most favored foreign language is the point of this article.

The article concentrates on the exploration that was done to quantify the best overwhelming foreign language among Higher Education Institutions. Additionally, article adjusted to dissect the viability of learning foreign languages among understudies in the bilingual setting.

All languages on the planet are perfect. For every nation for every individual, their own particular language is perfect. In addition, in a few conditions, an objective language turns into a perfect or even local language. Every language always showing signs of change, all things considered, proceeding with the requirement for adjustment is more typical. What you needed to state and how you said it - amongst substance and expression is called a perfect language [4]. Author concurs with this point; language is an awesome method for distinguishing the social qualities, nationality and end up noticeably perfect. Changing social and scholarly needs may bring about individuals' talking in different languages. Notwithstanding changing the living spot implies changing language yet with the blended encompassing. Along these lines, the language relies on upon its place and circumstance.

Taking in a language and truly giving it something to do that will make us emerge. Children, as well as creatures; winged animals, felines, mutts, can copy the sounds and examples which they hear around. Also, people proceed to mimic and practice these sounds and examples until they frame "propensities "of right language utilize. This assumes an imperative part in future life. By making this as habit" of correct language the child will get success in language learning [13]. The passage examines that; the investigation of language can't be likened with the investigation of history or 
math due to more than comprehension; it includes adjusting to a specific custom of an alternate social gathering.

As the paper examines, the language is overwhelming and pioneer the examination additionally demonstrates that language is exceptional and most much of the time utilized one. It is first important to comprehend the assets that a language makes accessible to its local speakers, the individuals who have gained it as kids in a characteristic setting. Since correspondence is not limited, language must accomplish something more than giving a bundle of instant messages. Language is more than correspondence. Language must be imaginative - enabling curiosity and advancement because of new encounters, circumstances, and contemplations. In country building language is a basic variable. At the point when the language is a decrease, the character of a country is in decay as well. Thus, every language has a profound authentic foundation identified with its country.

\subsection{Multilingualism in Azerbaijan}

When we speak, or examine about learning, language arranging, the best language, particularly about styles in Azerbaijan, it is difficult to talk or to give a case from Soviet circumstances [12]. Azerbaijan's country and language have a long history. Surviving intrusion by the Russian Empire and afterward the Soviet Union, Azerbaijanis figured out how to safeguard their national personality and local language. The time of seven decades under Soviet lead brought about sociolinguistics issues for the nation. The orthography of the Azerbaijani language was moved to Cyrillic by the Russian Empire in 1939, near the script of the Russian language. Despite every one of these weights and stresses, Azerbaijani country figured out how to save the national character of its first language, traditions, and customs under Soviet-run the show.

After the crumple of the Soviet Union, Azerbaijan proclaimed its freedom from the Union. These years can be described as the seasons of country building, language building, and recreation. Amid these years Azerbaijan has advanced an approach to change, as well as a youthful autonomous nation, has dealt with the ethnic minority language inside Azerbaijani outskirts. Of course, Azerbaijan is the country of various ethno semantic gatherings that talk languages of various family gatherings. As indicated by the 1999 insights in Azerbaijan, the minority gatherings were Lezgins, constituting 2.2\%, Russians 1.8\%, Armenians 1.5\%, Talysh $1.0 \%$, Avar $0.6 \%$, Tat $0.13 \%$, Georgians $0.2 \%$, Kurds $0.2 \%$, Jews $0.1 \%$ and different nationalities $0.12 \%$ of the aggregate populace in Azerbaijan (Library of President. The Population: 32). These previously mentioned ethnicities in Azerbaijan have a place with the accompanying language gatherings: North Caucasian, Indo-European, Afro-Asiatic and Kartvelian. As per the insights of 1999, Lezgins were the greatest minority bunch in Azerbaijan. [1].

In the difference to the Soviet years, the minority countries were currently given open doors in their own languages. In 1992, Article 6 of the seventh October law on Education and
Article 3 of the state language law guaranteed the minority countries the rights and instructive open doors in their local tongues.

These days, certain issues still stay in the change of the Azerbaijani language to be prevailing. One of the present errands on the ways toward language approach can be viewed as the need to diminish various Russian schools staying as the piece of the previous Soviet Union "Russification" arrangement. Considering that, the quantities of Russian schools have not diminished in Azerbaijan these days; one may believe that Russian has an indistinguishable status from in the times of Soviet Union. As indicated by the State Statistics Committee in Azerbaijani, the quantity of understudies going to state and private Russian schools was 108,240 students in the 2000-2001 year, and in the 20052006 years it constituted 108,737 understudies; additionally, starting in the year 2006-2007 the number begins tumbling down to 108,257 , while in 2009-2010 this figure is shown to be 95,567 understudies [14]. Considering the year 20092010 , out of $1,260,600$ students 95,567 understudies went to the Russian state and non-public schools in Azerbaijan [ibid]

Under Soviet manage, the Russian language assumed a part in country building and as a language of approach. Russian was viewed as the state language alongside Azerbaijani. Russian assumed the part of the most widely used language among 14 Soviet Union nations (counting Russia, the Soviet Union nations numbered 15). The strategy of the Soviet Union comprised of change of the Russian language among the Union nations with the objective of step by step achieving the most abnormal amount, accomplishing Russophones in the Union nations. Notwithstanding, as indicated by the 1989 evaluation 97.7 percent of Azerbaijan considered Azerbaijani their local and legacy tongue [5]. In addition, most of the world-class comprised of Russophones. In 1959 in Azerbaijani, 837 books were imprinted in Azerbaijan and 283 books were imprinted in Russia, while in 1979 the quantity of Azerbaijani books was 834 books (three books under 1959), while Russian books numbered 430 books (147 books more than 1959) imprinted in Azerbaijan $[1]$.

In that time, amid the Soviet Union, foreign language didn't have any need. In addition, the Russian language wasn't as a foreign language. At schools, the adage Russian division was more utilized and it was a moment language. Individuals needed their kids to know close to the primary language the very much utilized Russian language. Thus, with learning and instructing our writing and history the Russian history and writing was taught well. Efficient arrangement appeared with such running the show. The estimation of the Russian language was high in spite of the way that Azerbaijani held the status of a state language. The general population with the absence of Russian learning was viewed as less present day.

The point of fact, the significance of the Azerbaijani language has essentially expanded inside 21 years of freedom. Rather, the Russian language is currently relentlessly moving to a broadly utilized L2 (second 
language) alongside the English language among the populace. The status of the Russian language is diminishing; the significance of English language is expanding in near terms with decades prior. From this point of view, a few researchers keep up Russian and English languages as a risk to the national virtue and danger to the advancement of main languages in Azerbaijan [11]. From creators perspective, the significance of Russian in Azerbaijan can abatement and exchange to the L2 talked status, if the quantity of Russian schools would increment. The following sensible stride, where the administration ought to roll out a steady improvement, is the field of essential and optional training segments.

The creator inferred that the significance and size of the Russian language and Russophone populace in Azerbaijan has lessened, yet not fundamentally vanished. The significance of the English language as a foreign language expanded after the freedom of the Republic of Azerbaijan. Also, Russian is still being used as a specialized strategy instead of as a foreign language in the nation. The measure of Russophone elites has reduced, however not vanished. Among the developing era, Azerbaijani is critical. Also, there are still families that permit their youngsters or grandchildren experience childhood in Russian. In any case, the change and improvement of the language ought to be tried for the long haul.

Generally, one might say that, Azerbaijan has a moderately liberal phonetics setting with a few indications of tip top multilingualism. Besides, in all cases populace pick foreign language particularly English for their better future conditions in light of the fact that, the advanced life and present day conditions make language wide utilize and considerably more demandable and furthermore as a method for correspondence which is fundamental for better training, for better living, for better learning and notwithstanding for better occupation. Starting there taking in the foreign language is so imperative and it will help completely set up Azerbaijani as the essential language of correspondence and encourage the learning of fancied languages on the other.

\subsection{Previous Research}

The investigation of sex is additionally one of the perspectives that attract a consideration this exploration with regards to the disposition towards language learning as a rule. Wright (1999) [15], Kobayashi (2002) [6], Cenoz (2001) [2] concentrates discovered noteworthy contrasts amongst male and female disposition towards learning languages; young ladies showed more uplifting demeanor towards language learning looked at young men. Cenoz (2001) [2] and Merisuo-Storm (2007) [9] found that accomplishment of understudies in second language learning relies on upon their state of mind to an objective language. The more uplifting disposition to foreign languages brings about higher accomplishments of understudies in L2. Another comparative research directed by Papaja (2012) [10], who concentrated the demeanor of college understudies towards foreign language learning in Poland. On the national level, this paper speaks to a spearheading endeavor to concentrate the English language in Azerbaijan.

\section{Method}

\subsection{Research Setting}

The exploration site is considered among two private Universities; Khazar University and Qafqaz University in Baku, Azerbaijan. The two utilize the English language as a moment foreign language for guidelines.

Khazar University was established in 1991. It is a private instructive organization for undergrad, graduate and expert reviews advancing propelled study and research, instructive approach and advancement in the Republic of Azerbaijan. Review at Khazar University was led on March 21st, 2015. Khazar was positioned first among Azerbaijan Universities concurring QS World University Rankings. Study at Khazar University was led on March tenth, 2015. The example understudies were chosen haphazardly. 158 understudies addressed $(\mathrm{n}=158$; female $96(60.8 \%)$, male $62(39.2 \%)$ mean age $=21(86.1 \%))$

Qafqaz University was established in 1993, by the pronouncement of the Azerbaijani Republic's National Assembly and endorsement by the Cabinet of Ministers. In QS World University Rankings, it positioned second among Azerbaijani Universities after Khazar University. Study at Qafqaz University was led on April 21st, 2016. The example understudies were chosen haphazardly. 143 understudies addressed $(\mathrm{n}=143$; female $63(55.9 \%)$, male $80(44.1 \%)$, mean age $=20(86 \%))$

\subsection{Research Questionnaire}

The motivation behind this examination is to investigate language arranging, the best foreign language learning as a moment language in a multilingual setting. The poll was selfcreated by the creator, who recognized four fundamental social elements (ethnic character, age, sex, social class). As indicated by the unmistakable socio-phonetic gathering in Azerbaijan, the review survey makes an inquiry on the language of optional school, L1 securing in the Azerbaijani setting. After the gathering of information, answers were amassed and arranged for investigation. Moreover, the review likewise analyzed among foreign language learners inspiration and reason. Taking after are the focuses that were contemplated:

1. Do you believe is it important to learn a foreign language?

2. Which foreign language do you consider the best in Azerbaijan? 2a. Why?

3. Which foreign language do you know best? Circle the suitable number from 1 to 8 . (1-least $\mid 8$-most extreme)

\subsection{Sampling Method}

This article concentrated its exploration on those individuals who are presented to instruction and foreign languages. The information is quantitative and by one-way were examination mean, mode, middle, go, change, standard 
deviation (SD), z-score and t-score.

The study was led from 2015-2016 scholastic years for the reason to decide the commonness of the best foreign. Understudies in different majors inside the examination test were stratified through stratified inspecting. Understudies with various majors for the led research were arbitrarily chosen. Members required in this review were 301 individuals from two private instructive foundations (Khazar University and Qafqaz University) in Azerbaijan. These members were purposively chosen because of their enthusiasm being multilingual. The times of the members differed near 18 and 29. Study inquiries were set up in paper and disseminated to every individual. Moral contemplations of the examination were considered: members at the review were deliberate; the members were educated about the exploration and the future destiny of the polls.

\subsection{Participants}

College understudies from two private instructive organizations (Khazar University, Qafqaz University) taken an interest in this study.

Table 1. Observed frequencies: Gender.

\begin{tabular}{ll}
\hline Gender of data & Valid number \& percent \\
\hline $\begin{array}{l}\text { Male } \backslash 0 \\
\text { including, }\end{array}$ & 171 \\
Khazar University & $62(39.2)$ \\
Qafqaz University & $80(55.9)$ \\
Female $\backslash 1$ & 130 \\
including, & \\
Khazar University & $96(60.8)$ \\
Qafqaz University & $63(44.1)$ \\
Total & 301 \\
Mean age (SD) & $21(86.0)$ \\
\hline
\end{tabular}

Totally, 301 valid responses were registered (female 159, male 142 , mean age $=21, \mathrm{SD}=86.0)($ See Table 1$)$.

\subsection{Data Analysis}

IBM ${ }^{\circledR}$ SPSS $®$ Statistics Data Editor (version. 23) was used to conduct statistical analyses.

\section{Findings}

Findings of statistical analyses on students' attitude to the best foreign language among two Higher Private Institutions (Khazar and Qafqaz University) in Azerbaijan are presented below.

Table 2. Observed frequencies: Age.

\begin{tabular}{lll}
\hline Age of data & frequency & valid percent \\
\hline Khazar University & & \\
$18-21(0)$ & 136 & 86.1 \\
$22-25(1)$ & 20 & 12.7 \\
$26-29(2)$ & 2 & 1.3 \\
Missing & 0 & 158 \\
Total & 158 & 100.0 \\
Qafqaz University & & \\
18-21 (0) & 123 & 86.0 \\
\hline
\end{tabular}

\begin{tabular}{lll}
\hline Age of data & frequency & valid percent \\
\hline $22-25(1)$ & 17 & 11.9 \\
$26-29(2)$ & 3 & 2.1 \\
Missing & 0 & 143 \\
Total & 143 & 100.0 \\
\hline
\end{tabular}

The descriptive statistics tests revealed that the mean age (.1519), Std. Deviation (.39386), Variance (.155), and Range (2.00) for Khazar University. For Qafqaz University the mean age (.1608), Std. Deviation (.42211), Variance (.178) and Range (2.00) (See Table 2).

Table 3. Observed frequencies: Question 1. Do you think is it necessary to learn a foreign language (FL)?

\begin{tabular}{lll}
\hline Category & frequency & valid percent \\
\hline Khazar University & & \\
Yes (0) & 155 & 98.1 \\
No (1) & 3 & 1.9 \\
Missing & 0 & 158 \\
Total & 158 & 100.0 \\
Qafqaz University & & \\
Yes (0) & 136 & 95.1 \\
No (1) & 7 & 4.9 \\
Missing & 0 & 143 \\
Total & 143 & 100.0 \\
\hline
\end{tabular}

The descriptive statistics tests revealed for question 1, that the mean (.1090), Std. Deviation (.13691), Variance (.019) and Range (1.00) for Khazar University. For Qafqaz University the mean (.0490), Std. Deviation (.21652), Variance (.047) and Range (1.00). The majority of participants answered YES. Out of 301 students 291 answered YES for necessity of learning a foreign language, 10 students indicated NO for the necessity of learning a foreign language. (see Table 3).

Table 4. Observed frequencies: Question 2. Which foreign language do you consider the best FL for Azerbaijan?

\begin{tabular}{lll}
\hline Category & frequency & valid percent \\
\hline Khazar University & & \\
English (0) & 146 & 92.4 \\
Russian (1) & 7 & 4.4 \\
Other (2) & 5 & 3.2 \\
Missing & 0 & 158 \\
Total & 158 & 100.0 \\
Qafqaz University & & \\
English (0) & 126 & 88.1 \\
Russian (1) & 10 & 7.0 \\
Other (2) & 7 & 4.9 \\
Missing & & \\
Total & 143 & 100.0 \\
\hline
\end{tabular}

The descriptive statistics tests revealed for question 2, that the mean (.1076), Std. Deviation (.40040), Variance (.160) and Range (2.00) for Khazar University. For Qafqaz University the mean (.1678), Std. Deviation (.48912), Variance (.239) and Range (2.00). Most participants preferred English. Out of 301 students 272 indicated English as the most preferred foreign language, 17 students indicated Russian as preferred, 12 students favored other language. (see Table 4).

The descriptive statistics tests revealed for question 3 , that 
the mean (.1076), Std. Deviation (.40040), Variance (.160) and Range (2.00) for Khazar University. For Qafqaz University the mean (.1678), Std. Deviation (.48912), Variance (.239) and Range (2.00). Students enrolled in private universities were more likely indicated as the best known language English. Out of 301 students 258 indicated English, 32 indicated Russian and 11students indicated as the best known language other. (see Table 4).

Table 5. Observed frequencies: Question 3. Which foreign language do you know best?

\begin{tabular}{lll}
\hline Category & frequency & valid percent \\
\hline Khazar University & & \\
English (0) & 127 & 80.4 \\
Russian (1) & 28 & 17.7 \\
Other (2) & 3 & 1.9 \\
Total & 158 & 100.0 \\
Qafqaz University & & \\
English (0) & 131 & 91.6 \\
Russian (1) & 4 & 2.8 \\
Other (2) & 8 & 5.6 \\
Missing & & \\
Total & 143 & 100.0 \\
\hline
\end{tabular}

\section{Results and Discussion}

This segment exhibits the fundamental discoveries of the review, which depend on the consequences of the overview directed to the understudies' in two Higher Private Educational Institutions. The exploration discoveries uncovered a critical support of foreign language and showed that English is the most favored foreign language in Azerbaijan. These discoveries add additional confirmation to the current writing that second language learning is attainable in multilingual settings. An overwhelmingly solid inclination for English in Azerbaijan, where $90 \%$ of the populace is bilingual in Russian and Azerbaijani, adds new information to the way that bilingualism is believed to be not just valuable for obtaining a third language, additionally emphatically influences states of mind to learn a third language all in all. In addition, there was a measurable huge connection amongst L1 and the mentality to language learning. Albeit both semantics gatherings (Azerbaijani and Russian speakers), were strong of English, the level of support among Azerbaijani speakers was higher. This review did not discover connection amongst sex and state of mind towards foreign language learning among male and female learners.

The information gathered on social class and pay level was restricted because of nearby conditions as clarified above, and discoveries ought to be translated carefully. The examination did not discover factually huge association with the variable of the possession type of the instructive establishments, which go about as intermediary for social class. Understudies from private colleges bolstered foreign language adapting practically on a similar level. Understudies enlisted in state-funded colleges were better towards English.
The solid connection between the states of mind to the English language merits consideration. Supporters of English language more probable $(90 \%)$, the individuals who did not bolster the English language (10\%). The acquired factual importance reveals some new insight into speculations of the connection between the language of instruction and second/foreign language obtaining, and state of mind. Look into recommends that, states of mind to language securing rely on upon dispositions towards the second/foreign language group, target language, and language learning. Also, L1 is by all accounts one of the essential components that influences the state of mind of learners towards English.

Future research would be valuable to look at the reasons of watched noteworthy connection amongst L1 and the dispositions to English to see if multilingual people are less ready to learn and extra language than monolinguals do or that getting instruction in Russian influences the state of mind of English in the Azerbaijani setting.

By and large, the discoveries recommend that multilingual social orders, for example, Azerbaijan, for the most part, bolster language learning approaches that help protect and improve multilingualism. This finding fortifies the idea advanced by Merisuo-Storm [9], who found that multilingual individuals are interested in taking in extra languages. Such a solid support for foreign language learning brings new space for moving for leaders in language strategy and arranging, for which the topic of which language is foremost significance. The examination draws on the human capacity to take in more than one language and makes the subject of "which single language" repetitive. For such language strategies, open support is an essential component and it is clearly present in Azerbaijan as it can be construed from this review. The likelihood of Russian is molded by the accessibility of assets, topographical, social, and political variables. The part of English is supported by its part as the worldwide most widely used language and the solid uplifting demeanor to this language among the populace as the discoveries from this work show.

\section{Appendix: Survey Questionnaire (Original)}

This survey questionnaire is made for the purposes of research by Valida Karimova, (PhD (c.) in Germanic languages).

The aim of the research is to find out the best foreign language among students' in the Higher Private Education Institutions.

Ethics: Participation in this survey is voluntary. You may refuse to respond this questionnaire without any negative consequences. Your responses will remain anonymous and confidential, and no information that could reveal your identity will be used.

Multilingualism in Azerbaijan: The most preferred foreign 
languages in private Universities of the country and its socioeconomic aspects.

Table A1. Research questionnaire step 1.

\begin{tabular}{|c|c|c|c|}
\hline \multicolumn{4}{|l|}{ Name } \\
\hline \multicolumn{4}{|c|}{ Surname } \\
\hline \multicolumn{4}{|c|}{ Affiliated education institute } \\
\hline Gender & Male $\square$ & & Female $\square$ \\
\hline Age & $18-21 \square$ & $22-25$ & $26-29 \square$ \\
\hline
\end{tabular}

Table A2. Research questionnaire step 2.

\begin{tabular}{l}
\hline RESEARCH QUESTIONS \\
\hline Do you think is it necessary to learn a foreign language? \\
\hline YES $\square$ \\
Which foreign language do you consider the best foreign language in \\
Azerbaijan? \\
$\begin{array}{l}\text { English } \square \\
\text { 2a. Why? }\end{array}$ \\
\hline
\end{tabular}

Table A3. Research questionnaire step 3.

Which foreign language do you know best? Circle the appropriate number from 1 to 8. (1-minimum $\backslash 8$-maximum)

\begin{tabular}{ll}
\hline English & 12345678 \\
Russian & 12345678 \\
Other (please specify) & 12345678 \\
\hline
\end{tabular}

\section{References}

[1] Balayev, A. (2007). The Ethno linguistics processes in Azerbaijan. pp. 9-13.

http://files.preslib.az/projects/remz/pdf/atr_dil.pdf.

[2] Cenoz, J. (2001). Three languages in contact: Language attitudes in the Basque Country. In D. Lasagabaster \& J. M. Sierra (eds), Language Awareness in the Foreign Language Classroom. Zarauz, University of the Basque Country.

[3] Devitt. M., \& Sterelny, K. (1938). Language and Reality an Introduction to the Philosophy of Language, second edition. pp. 3-5, pp. 275-281.

[4] Finnegan, E. ( $3^{\text {rd }}$ edition). Language: Its Structure and Use. Retrieved November 28, 2015.
[5] Grenoble, A. L. (2003). Language Policy in the Soviet Union.

[6] Kobayashi, Y. (2002). The role of gender in foreign language learning attitudes: Japanese female students' attitudes towards learning English. Gender Edu, 14, pp. 181-197. http://dx.doi.org/10.1080/09540250220133021.

[7] (2012) How to Learn a Foreign Language. http://www.studymode.com/essays/How-To-Learn-a-ForeignLanguage-913543.html.

[8] (2009) Importance of Learning a Foreign Language. http://answers.yahoo.com/question/index?qid=200909210850 42AAUO9Kkk.

[9] Merisuo-Storm, T. (2007). Pupils' attitudes towards foreignlanguage learning and development of literacy skills in bilingual education. Teaching Teacher Edu, 23, 226-235. http://dx.doi.org/10.1016/j.tate.2006.04.024.

[10] Papaja, K. L. (2012). The impact of students' attitudes on CLIL. Latin American Journal of Content \& Language Integrated Learning. 5 (2), pp. 28-56. http://dx.doi.org/10.5294/lacli1.2012.5.2.10.

[11] Pavlenko, A. (Ed.). (2008). Multilingualism in post Soviet Countries. Clevedon, Uk: Multilingual Materials.

[12] Shafiyeva, U., \& Kennedy, S. (2010). English as a Foreign Language in Azerbaijan: English Teaching in the post-Soviet era.

http://journals.cambridge.org/action/displayAbstract?fromPag $\mathrm{e}=$ online\&aid $=72840200$.

[13] Smolinski, F. (1993). Landmarks of American Language of Linguistics, volume I. pp.40-65.

[14] State Statistics Committee of the Republic of Azerbaijan. (2014). Education, Science and Culture. http://www.stat.gov.az/source/education/indexen.php.

[15] Wright, M. (1999). Influences of learner attitudes towards foreign language and culture. Educational Research, 41, pp. 197-208. http://dx.doi.org/10.1080/0013188990410207.

[16] http://sia.az/ru/news/fashion/363445-azerbaycanlaingilterenin-medeni-inteqrasiyasi-xix-xx-esrler.

[17] http://www.amerikaninsesi.org/content/history-ofenglish/1573283.html. 